\title{
MOVEMENT PATTERN OF Spartocera dentiventris (BERG) (HEMIPTERA: COREIDAE) IN AN EXPERIMENTAL CROP OF Nicotiana tabacum L. (SOLANACEAE)
}

\author{
JESUS, C. R., ${ }^{1}$ ROMANOWSKI, H. P. ${ }^{2}$ and REDAELLI, L. R. ${ }^{3}$ \\ 1,3 Departamento de Zoologia, PPG Biologia Animal, UFRGS, Av. Bento Gonçalves, 9500, \\ Bloco IV, Prédio 43435, CEP 91501-970, Porto Alegre, RS, Brazil \\ ${ }^{2}$ Departamento de Fitossanidade, Faculdade de Agronomia, PPG, Biologia Animal, UFRGS, \\ Av. Bento Gonçalves, 7712, CEP 91540-000, Porto Alegre, RS, Brazil \\ Correspondence to: Cristiane Ramos de Jesus, rua Antônio Josephino Perrone, 113, CEP 91770-780, \\ Porto Alegre, RS, Brazil, e-mail: crjesus@vortex.ufrgs.br \\ Received August 28, 2001 - Accepted April 2, 2002 - Distributed November 30, 2002
}

(With 5 figures)

\begin{abstract}
In the present work we investigated the movement pattern of Spartocera (=Corecoris) dentiventris (Berg) (Hemiptera: Coreidae) adults through the mark-release-recapture method in an experimental tobacco crop (Nicotiana tabacum L., Solanaceae) in Porto Alegre, RS, Brazil. We marked 217 specimens from August 1999 to April 2000. Females moved $2.94 \pm 0.198$ times and males $1.46 \pm$ 0.171 times among host plants. The number of movements per capture was $0.53 \pm 0.03$ for females and $0.54 \pm 0.06$ for males. Newly recruited adults took $12.75 \pm 0.919$ days to leave their original plant, females moved $9.87 \pm 0.711 \mathrm{~m}$ and males $9.16 \pm 1.29 \mathrm{~m}$ in this first movement. We estimate that females move an average of $26.22 \mathrm{~m}$ and males $13.89 \mathrm{~m}$ during their permanence in the area.
\end{abstract}

Key words: movement, dispersion, mark-release-recapture, Spartocera dentiventris.

\section{RESUMO}

Padrão de movimento dos adultos de Spartocera dentiventris (Berg), (Hemiptera: Coreidae) em um cultivo experimental de Nicotiana tabacum L. (Solanaceae)

O padrão de movimentação dos adultos de Spartocera $(=$ Corecoris) dentiventris (Berg) (Hemiptera: Coreidae) foi investigado por meio do método de marcação e recaptura, em cultivo experimental de fumo (Nicotiana tabacum L., Solanaceae) em Porto Alegre, RS, Brasil. Foram marcados 217 indivíduos no período de agosto de 1999 a abril de 2000; as fêmeas movimentaram-se 2,94 $\pm 0,198$ vezes e os machos, $1,46 \pm 0,171 \mathrm{vez}$ entre as plantas hospedeiras. O número de movimentos registrados por recaptura foi de $0,53 \pm 0,03$ para fêmeas e de 0,54 $\pm 0,06$ para machos. Os adultos recém-recrutados levaram 12,75 $\pm 0,91$ dias para dispersar de sua planta de origem; as fêmeas percorreram 9,87 $\pm 0,711$ $\mathrm{m}$ e os machos, 9,16 $\pm 1,29 \mathrm{~m}$ nesse primeiro movimento. Estima-se que as fêmeas percorram durante sua permanência na área uma média de $26,22 \mathrm{~m}$, e os machos, 13,89 m.

Palavras-chave: movimento, dispersão, marcação e recaptura, Spartocera dentiventris.

\section{INTRODUCTION}

Spartocera (=Corecoris) dentiventris, the tobacco-gray-bug, is cited as a tobacco pest because it damages leaves by sucking on them, causing leaves to wilt and twist (Costa, 1958; Bertels, 1962; Silva et al., 1968; Schaefer \& Mitchell, 1983).
In general, $S$. dentiventris colonizes the tobacco culture by the end of August, and them two further generations may occur until the end of March, when the plants die off. Canto-Silva (1999) observed nymphal dispersal only within the same plant registered, but adult movement between plants. This author suggested that the period 
of higher movement rates seems to be the postteneral one. Despite this information, there is a lack of precise data about adult movement and its variability.

In fact, our field observations during colonization, $S$. dentiventris seem to confirm CantoSilva (1999). For the following generations, soon after the recruitment for the adult phase, individuals disperse to new plants reaching considerable distances. During other development phases, movement seems to be less frequent and occurs in much shorter distances, mostly within plant.

The movement pattern of individuals is determined both by intrinsic factors (age structure of the population and individual variation in mobility) and extrinsic ones such as weather conditions and habitat heterogeneity (Kennedy \& Storer, 2000).

In this work the movement patterns of $S$. dentiventris adults in the experimental area was investigated, verifying possible relations between these movement patterns, the period of adult recruitment and the phenology of the tobacco plants.

\section{MATERIAL AND METHODS}

This work was carried out in the experimental area of the Departamento de Fitossanidade, Universidade Federal do Rio Grande do Sul, in Porto Alegre $\left(30^{\circ} 01^{\prime} S\right.$ and $\left.50^{\circ} 13^{\prime} \mathrm{W}\right)$, South Brazil. On the $3^{\text {rd }}$ of August 1999, 270 Virginia (variety K326) tobacco seedlings were planted in 10 rows spaced $0.8 \mathrm{~m}$ from each other and with $1.0 \mathrm{~m}$ between rows in an area of approximately $300 \mathrm{~m}^{2}$. All plants were coded with alphanumeric coordinates, where each row was identified by a letter and each plant in the row by a number.

Samples were taken daily always in the morning, from the $3^{\text {rd }}$ of August 1999 to the $5^{\text {th }}$ of April 2000. This period corresponds to the tobacco culture cycle. Samples were taken daily until the $8^{\text {th }}$ of November, when the colonizing generation was totally settled in the area. Subsequent samplings were done three times a week. In each sampling occasion all plants were inspected, adult individuals were manually captured, marked and put back to the same plant. Marks were made with a permanent ink marker, and were based on the Brussard point code system (Southwood, 1978). We registered the code number, sex and plant coordinate of all individuals captured.
In order to accurately monitor the period of adult recruitment and eventual variation in the movement patterns in this phase, immature stages were observed during development. We observed all plants with eggs laid by the colonizing generation. In the subsequent generation, given the considerable increase in the bug population density, we chose 12 plants to be closely observed. Thus, it was possible to register the newly recruited adults following the $5^{\text {th }}$ instar nymphs.

For the calculation of the minimum distance accomplished by adult individuals we applied the following equation: $\mathrm{d}=\sqrt{\Delta \mathrm{x}^{2}+\Delta \mathrm{y}^{2}}$, where $\mathrm{d}$ is the minimum distance moved (hypothenuse); $\Delta \mathrm{x}$ the distance between rows (in $\mathrm{m}$ ); and $\Delta \mathrm{y}$ the distance between plants in the rows (also in $\mathrm{m}$ ).

To test any differences in movement rates obtained for males and females, we used the Kolmogorov-Smirnov test. Values are shown in averages $\pm \mathrm{SE}$.

\section{RESULTS AND DISCUSSION}

The colonization of tobacco culture by $S$. dentiventris started on 6 September 1999. The colonising generation was composed of 17 females and 14 males. Jesus \& Romanowski (2001) registered the beginning of colonization on 26 August 1997 and a colonizing generation composed of 22 females and 24 males in a work carried out in the same area. Besides the colonizing generation, only a further generation completed development up to the adult phase during the period the present study was carried out.

Along the 125 sampling occasions, we marked 217 adult individuals of $S$. dentiventris, being 131 females and 86 males. Percentage of recaptures was extremely high, at about $96 \%$ for females and $79 \%$ for males (Fig. 1a). This high sampling intensity gives support to the results obtained, since almost all $S$. dentiventris adults in the area were sampled.

Females moved on average $2.94 \pm 0.198$ times and males $1.46 \pm 0.171$ times during the culture cycle. We detected a significant difference between the number of times females and males moved $\left(\chi^{2}=14.71 ; \mathrm{gl}=2 ; \mathrm{p}=0.006\right)$. Females moved a maximum of 12 times, while for males the maximum was 6 (Fig. 1b). Canto-Silva (1999) in a work carried out in the same area obtained values only marginally higher for females: average 
movements per individual along the culture cycle was $1.37 \pm 0.07$ for females and $1.33 \pm 0.05$ for males. These figures are quite similar to the ones found for males in the present study, but less than half the number estimated for females. Canto-Silva (1999) registered females and males moved a maximum of 4 times. These lower numbers obtained, by Canto-Silva (1999) probably are due to the lower sampling intensity of adults on that study (about 47\%) which may explain the discrepancy with results shown here.

The number of movements registered by capture event was similar for males and females $(Q=0.53 \pm$ 0.03 ; $\sigma=0.54 \pm 0.06$ ). We registered a weak corre- lation, although highly significant, between the number of recaptures and the amount of detected movements both for females $\left(\mathrm{r}^{2}=0.184 ; \mathrm{gl}=81 ; \mathrm{p}<0.001\right)$ and for males $\left(\mathrm{r}^{2}=0.2683 ; \mathrm{gl}=56 ; \mathrm{p}<0.001\right)$. This indicates that the number of registered movements depend on the number of recaptures, but also that other factors may have an important role. As the sampling intensity and the number of recaptures by individual were extremely high, we believe our results were not biased because of this.

In general, females were recaptured more often and seemed to move more across the culture, possibly searching for an adequate plant for oviposition and development of their offspring.
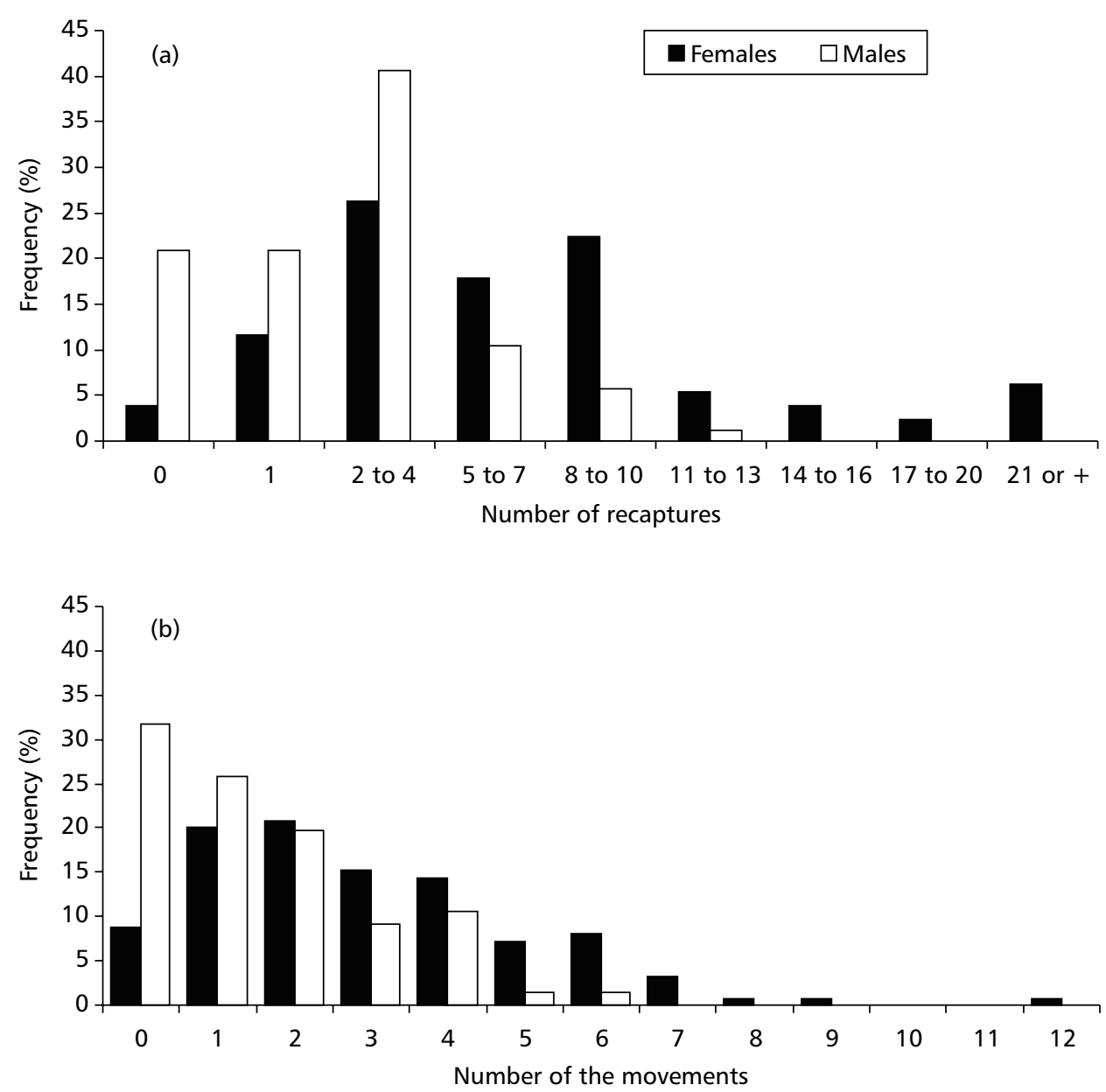

Fig. 1 - Number of recaptures (a) and number of movements by the recaptured adults of Spartocera dentiventris (b) in an experimental tobacco plot. Porto Alegre $\left(30^{\circ} 01^{\prime} \mathrm{S}\right.$; $\left.51^{\circ} 13^{\prime} \mathrm{W}\right)$, South Brazil. 
Females of $S$. dentiventris moved on average $0.75 \pm 0.13 \mathrm{~m} /$ day. Studies of this nature are very rare on the literature; no reports on coreids were found. Sujii et al. (2000) working with Deois flavopicta Stal (Hemiptera: Cercopidae) adults in Brachiaria ruziziensis Stapf (Poaceae) found an average movement of $5 \mathrm{~m} /$ day, much higher than that found for $S$. dentiventris. This is not surprising since the species moves mainly by short low jumping flights (bellow $1 \mathrm{~m}$ ).

Considering the estimated longevity of females of $S$. dentiventris $(31.1 \pm 1.88$ days $)$ we estimated that on the average they would move 4.89 times/day and would cover $26.22 \mathrm{~m}$ across the cultivation area. Males, whose estimated longevity was of $15.29 \pm 1.83$ days, moved at least $0.65 \pm 0.14 \mathrm{~m} /$ day and are able to move 4.57 times/ day and run cover, on average, a total of 13.89 $\mathrm{m}$ during their permanence in the culture.

Adults that colonized the area accomplished distances which ranged from 1 to $20 \mathrm{~m}$. Most of these females $(58.3 \%$ ) moved up to $2 \mathrm{~m}$. That was possibly due to the fact that tobacco plants are free from other herbivore competitors in this phase of the cultivation, and thus females did not need to search much for a place to settle (Fig. 2).
We analysed the movement pattern in relation to different periods of the adult phase. Newly recruited adults took $12.75 \pm 0.92$ days on the average to disperse $(Q=11.63 \pm 0.96 ; O=15.5 \pm 2.15$ (Fig.3) $)$. The frequencies distribution of the number of days passed since the recruitment until the first adult movements were registered is extremely skewed to the right for both sexes, however in different ways. For females the distribution is unimodal $(37 \%$ of females recruited leave the original plant in a period of five days) decreasing slowly, such that $70 \%$ of females had changed plant by the $15^{\text {th }}$ day. Males also presented a higher frequency (33\% of the 72 recruited males) of movement in the interval of 0 to 5 days. However, there is a second peak of movement $(22 \%)$ in the interval of 16 to 20 days, and a smaller third peak (12.5\%) at 31 to 35 days. It is suggested that after recruitment, females soon look for available plants for oviposition, whilst the movement pattern of males may be related with the search for new females to copulate. This differs from what was registered by Steinbauer \& Clarke (1998), who observed that males of Amorbus obscuricornis Westwood (Hemiptera: Coreidae) remained more time in the host plant ( 7 to 56 days) than females (up to 7 days).

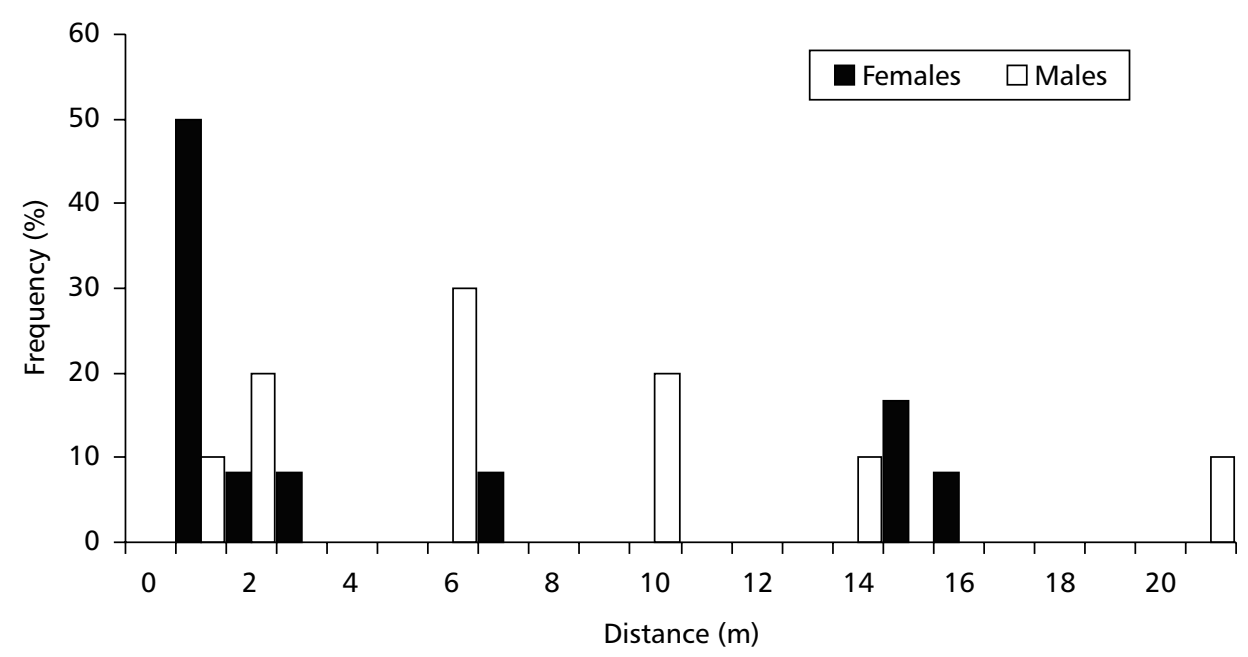

Fig. 2 - Minimum distance moved per recapture by adults of Spartocera dentiventris in the colonisation period in an experimental tobacco plot. Porto Alegre ( $\left.30^{\circ} 01^{\prime} \mathrm{S} ; 51^{\circ} 13^{\prime} \mathrm{W}\right)$, South Brazil. 


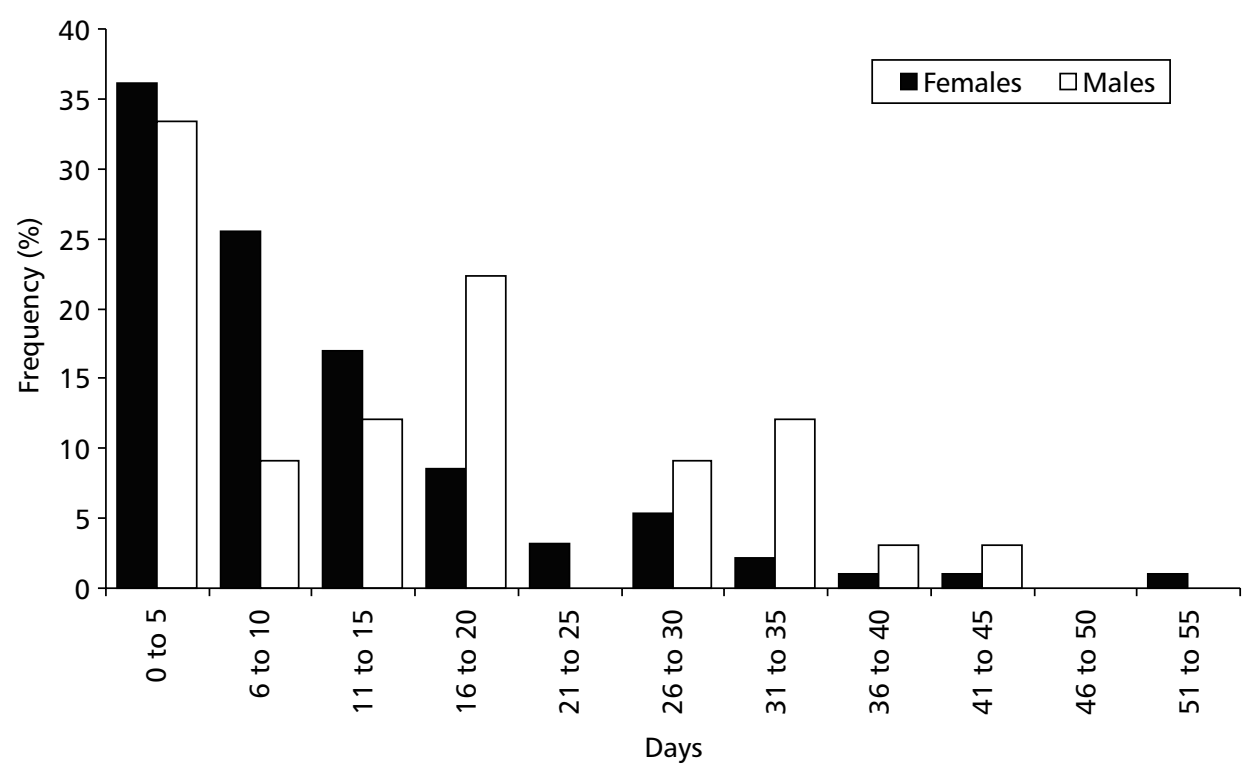

Fig. 3 - Number of days until first movement between plants after the recruitment of adults of Spartocera dentiventris for females and males in an experimental tobacco plot. Porto Alegre (3001'S; 51 ${ }^{\circ} 13^{\prime}$ W), South Brazil.

We did not detect any association between the number of days that the individuals took to leave the plant and the density of $S$. dentiventris adult individuals in the plant $\left(Q: \mathrm{r}^{2}=0.103 ; \mathrm{gl}=113\right.$; $\mathrm{p}=0.330 ;$ and $\left.\sigma^{\prime}: \mathrm{r}^{2}=0.0779 ; \mathrm{gl}=71 ; \mathrm{p}=0.1156\right)$.

Analysis of newly-recruited individuals showed that females disperse $9.87 \pm 0.711 \mathrm{~m}$ on average and males $9.16 \pm 1.29 \mathrm{~m}$, and these values are not significantly different $\left(\chi^{2}=1.34 ; \mathrm{gl}=2 ; \mathrm{p}=0.51\right)$. Although the distance covered by females afterrecruitment is relatively short, it may be reflecting a higher post-recruitment movement for settling on a new plant. The distance of the first after-recruitment movement too was not associated with the density of individuals in the original plant (Q: $\mathrm{r}^{2}=0.1086$; $\mathrm{gl}=81 ; \mathrm{p}=0.0012 ;$ and $\sigma^{\prime}: \mathrm{r}^{2}=0.1061 ; \mathrm{gl}=56$; $\mathrm{p}=0.1202)$. Canto-Silva (1999) registered an average distance of $8.79 \pm 0.65 \mathrm{~m}$ for females and $8.95 \pm 1.23 \mathrm{~m}$ for males, also not significantly different between sexes.

Movement of newly recruited individuals to the adult stage seems to be characteristic of this species, however we did not detect a significant difference between the distribution of frequencies of distances covered in the first movement after recruitment and subsequent movements for females $\left(\chi^{2}=0.22 ; \mathrm{gl}=2 ; \mathrm{p}=0.89\right.$, Fig. 4a). However, this difference was significant for males $\left(\chi^{2}=11.93\right.$; $\mathrm{gl}=$ $2 ; \mathrm{p}=0.026$ ) (Fig. 4b). On the other hand, distribution of frequencies of distances covered in the first movement after recruitment follows a clearly bimodal pattern ( $Q=1$ and $18 ; \sigma=4$ and 19 meters). For subsequent movements, we also observed an asymmetric distribution, but without marked peaks and with a wider variation amplitude. It is possible that females look first for an adequate plant to settle and oviposit near the origin plant, and later, if they do not find any, they move to more distant places. Higher modes for males than for females may be indirectly indicating that males move more to "pursue" females in order to find mates to copulate.

To verify whether the movement pattern varies also during the rest of the adult life, we took the number of captures as indications of the insect age and analysed the distance covered along successive recaptures of each individual (Fig. 5). A tendency of individuals to move more when relatively younger seems to occur and this pattern is similar for females and males.

In this study $S$. dentiventris showed a trend of not moving much within the culture during its cycle. Dreyer \& Baumgärtner (1997) relate that Clavigralla tomentosicollis Stal (Hemiptera: Coreidae) have a great mobility with a low index (4\% to $6 \%)$ of 
individuals recaptured and a permanence of less than two weeks in the culture. S. dentiventris, however has shown to be able to move quite long distances in certain periods such as after-recruitment, and move frequently in considerably short distances during its permanence in the culture. Contrastingly, some individuals, mainly females, remained in the same plant for all their lives or moved very little. In some cases the presence of up to three females ovipositing in the same place in the plant was observed.
Though the species has shown on the average a moderate dispersing ability, it has the capacity to cover distances of more than $50 \mathrm{~m}$ (Fig. 4) in a single movement. We highlight also the importance of analysing the movement patterns in different periods of the insect adult phase, once we found different tendencies for moving during colonization and soon after adult recruitment. These features may suggest ways to monitor the populations of this potential pest in space and time.
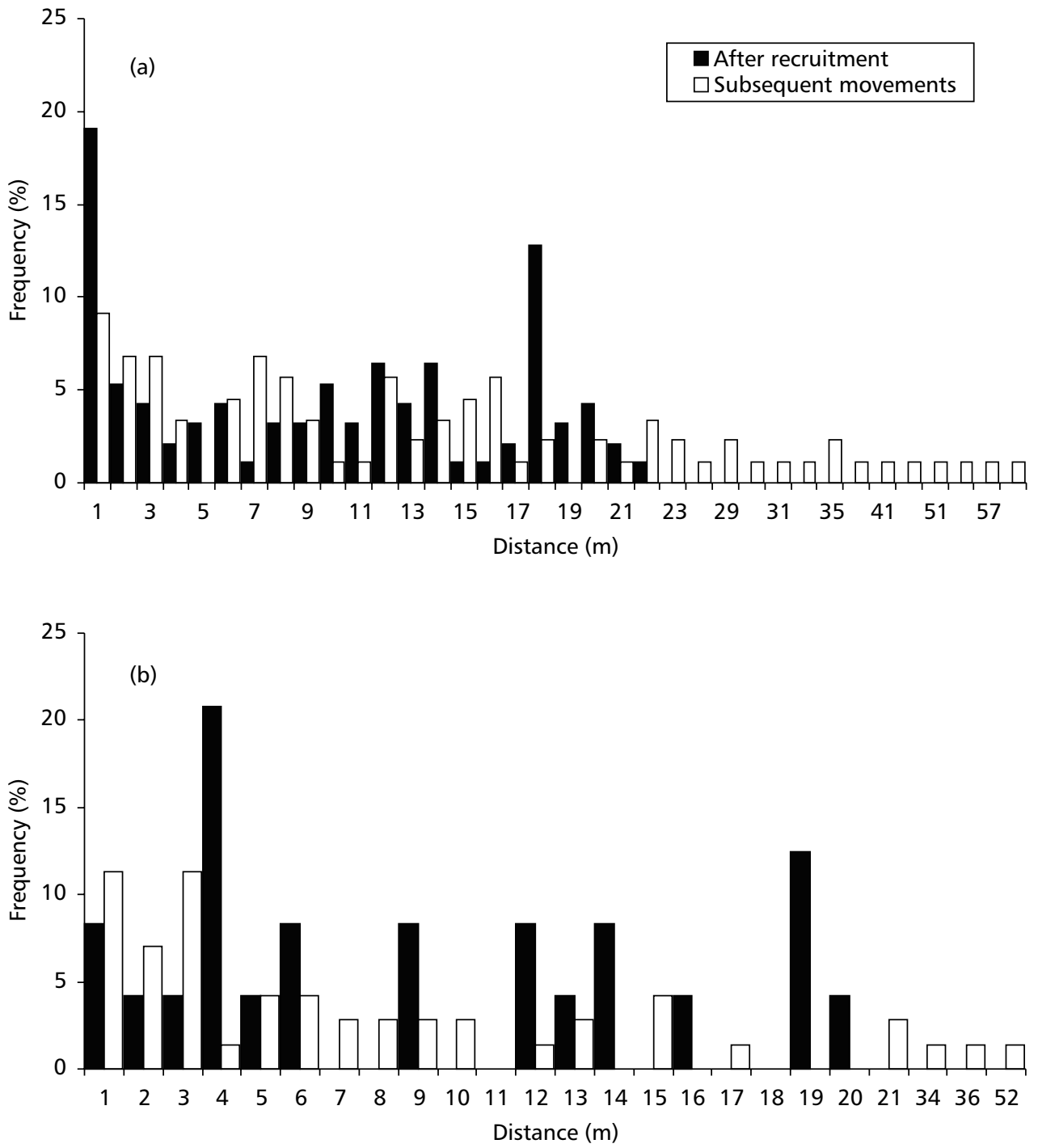

Fig. 4 - Minimum distance covered by females (a) and males (b) of Spartocera dentiventris recaptured in dispersion after recruitment and in subsequent movements in an experimental tobacco plot. Porto Alegre (30 01'S; 51 $\left.{ }^{\circ} 13^{\prime} \mathrm{W}\right)$, South Brazil. 

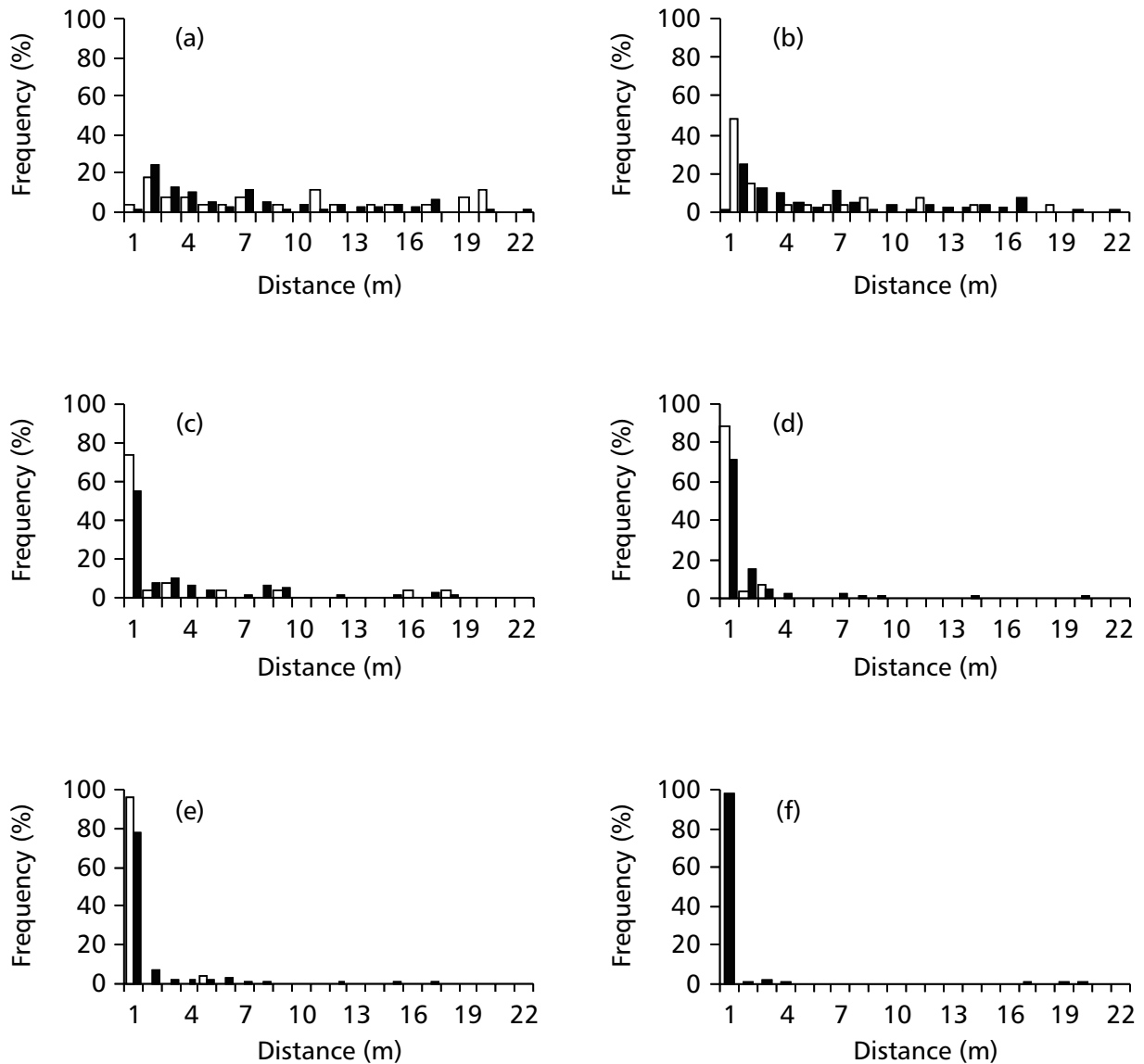

Females $\square$ Males

Fig. 5 - Minimum distance covered by females ( $\mathbf{\square}$ ) and males ( $\square$ ) of Spartocera dentiventris in subsequent recaptures in an experimental tobacco plot $(\mathrm{a}=$ second recapture, $\mathrm{b}=$ third recapture, $\mathrm{c}=$ quarter recapture, $\mathrm{d}=$ fifth recapture, $\mathrm{e}=$ sixth recapture, and $\mathrm{f}=$ above seven recaptures). Porto Alegre $\left(30^{\circ} 01^{\prime} \mathrm{S} ; 5^{\circ} 13^{\prime} \mathrm{W}\right)$, South Brazil.

Acknowledgments - The authors would like to thank Dr. Milton de Souza Mendonça Júnior for comments, suggestions and reviewing the English version of this manuscript.

\section{REFERENCES}

BERTELS, A., 1962, Insetos - hóspedes de solanáceas. Iheringia, 25: 1-11.

CANTO-SILVA, C. R., 1999, Aspectos da dinâmica populacional e distribuição espacial de Corecoris dentiventris em cultivo de Nicotiana tabacum. M.Sc. Dissertation, Universidade Federal do Rio Grande do Sul, Programa de Pós-graduação em Ecologia, Instituto de Biociências, Porto Alegre, 167p.
COSTA, R. G., 1958, Alguns insetos e outros pequenos animais que danificam plantas cultivadas no Rio Grande do Sul. Secretaria da Agricultura, Porto Alegre, 296p.

DREYER, H. \& BAUMGÄRTNER, J., 1997, Adult movement and dynamics of Clavigralla tomentosicollis (Heteroptera: Coreidae) populations in cowpea fields of Benin, West Africa. J. Econ. Entomol., 90(2): 421-426.

JESUS, C. R. \& ROMANOWSKI, H. P., 2001, Population dynamics of Corecoris dentiventris Berg, 1884 (Hemiptera: Coreidae) at an experimental tobacco crop in Porto Alegre, RS, Brazil. Biotemas, 14(2): p. 47-60.

KENNEDY, G. G. \& STORER, N. P., 2000, Life systems of polyphagous arthropod pests in temporally unstable cropping systems. Ann. Rev. Entomol., 45: 467-493. 
SCHAEFER, C. W. \& MITCHELL, P. L., 1983, Food plants of the Coreoidea (Hemiptera: Heteroptera). Ann. Soc. Entomol. Am., 76: 591-615.

SILVA, A. G. A., GONÇALVES, C. R., GALVÃO, D. M., GONÇALVES, A. J. L., GOMES, J., SILVA, M. N. \& SIMONI, L., 1968, Quarto catálogo dos insetos que vivem nas plantas do Brasil, seus parasitos e predadores. Ministério da Agricultura, Rio de Janeiro, Parte II, 2o tomo, 622p.

SOUTHWOOD, T. R. E., 1978, Ecological methods, with particular reference to the study of insect populations. Chapman \& Hall, London, 2 ed., 524p.
STEINBAUER, M. J. \& CLARKE, A. R., 1998, Field observations of dispersion, mating and development of Amorbus obscuricornis (Westwood) (Hemiptera: Coreidae). Austr. J. Entomol., 37: 155-157.

SUJII, E. R., GARCIA, M. A. \& FONTES, M. G., 2000, Movimentos de migração e dispersão de adultos da cigarrinha-das-pastagens. Pesq. Agropec. Bras., 35(3): 471-480. 